\title{
Expansion of the myotonic dystrophy gene in Italian and Spanish patients
}

Salvatore Melchionda, Ana Cobo, Massimo Gennarelli, Loreto Martorell, Cristina Fattorini, Montserrat Baiget, Adolfo Lopez De Munain, Keith Johnson, Peggy Shelbourne, Giuseppe Novelli, Bruno Dallapiccola

\begin{abstract}
Myotonic dystrophy results from expansion of a (CTG)n repeat at the 3 ' untranslated region of the myotonin-protein kinase gene. We show here the genomic analysis of 322 symptomatic patients with the cDNA-25 probe detecting disease specific EcoRI restriction fragments. The expansion was found in the majority of Italian and Spanish patients $(92 \%)$. The implications of these results for the detection of symptomatic patients in southern Europe are discussed.

(f Med Genet 1992;29:789-90)
\end{abstract}

Myotonic dystrophy (DM) is the most common inherited neuromuscular disease in adults, with an estimated world wide prevalence of 1 in 8000 persons. ${ }^{1}$ DM segregates as an autosomal dominant mutation with marked expressivity and pleiotropic effects including myopathy, cataracts, and cardiac arrhythmias. ${ }^{1}$ Affected families may exhibit genetic anticipation of the disease, defined by the appearance of increasing severity in successive generations. ${ }^{1}$ The molecular basis of DM has recently been elucidated by positional cloning of DNA probes isolated from the $19 \mathrm{q} 13.3$ region. $^{2-5}$ cDNA-25, MDY1, GB2.6, and M10M-6 probes detect disease specific restriction fragments, larger than those found in unaffected subjects. These fragments, which are variable in length and increase in size within DM families in parallel with the severity of the disease, have provided a biological basis for anticipation. ${ }^{16}$ The genomic region associated with this new allelic mutation has been characterised and found to contain a variable number of CTG repeats in the $3^{\prime}$ untranslated region of an mRNA coding for a member of the protein kinase family, identified as myotonin-protein kinase (MT-PK)..$^{56}$

We have investigated $122 \mathrm{DM}$ families from Italy and Spain. A total of 322 symptomatic patients was analysed from these pedigrees. Clinical diagnosis was performed according to the criteria of Harper ${ }^{1}$ and the definition of the working group on the molecular defect in DM. ${ }^{7}$ The control population consisted of 156 unrelated adult donors to the Italian Blood Transfusion Centre, Red Cross, Rome. Genomic DNA from these controls was examined with a cDNA probe (cDNA-25) which detects an EcoRI polymorphism ${ }^{2}$ of 9 and $10 \mathrm{~kb}$ fragments, with a frequency of 0.58 and 0.42 , respectively.

In 296 out of $322(92 \%)$ DM patients, the same probe detected new disease specific fragments larger than $10 \mathrm{~kb}$ (table). In all meioses examined, the expanded allele was cosegregating with the disease. This expansion showed intrasib variation and increased in subsequent generations. In the present set of families we found no offspring with a band corresponding to the expanded allele smaller than that observed in the parents carrying DM. The expansion was not found in $26(8 \%)$ unrelated, minimally affected subjects, who showed low grade amplification of this region not shown by Southern blotting. In all these subjects the disease had late onset and the most consistent clinical finding was cataract. Conversely, each of their affected offspring had a large fragment, confirming the unstable nature of this mutation. ${ }^{68}$ Furthermore, low grade expansions were detected in these 26 patients using the polymerase chain reaction (PCR, data not shown). In a few patients, an extended and faint smear was observed on Southern blots, as a consequence of a high degree of somatic heterogeneity. This result has been observed previously in other DM studies ${ }^{8}$ and in subjects with the fragile $\mathrm{X}$ syndrome. ${ }^{9}$ No evidence of a new mutation was found in 12 pedigrees with isolated cases of DM. In fact, in each instance, the cDNA-25 probe showed that one parent carried the mutation. Since congenital DM pedigrees were excluded from this study, no consistent phenotypic difference was observed in respect to the maternal versus the paternal origin of the mutation.

Our findings compare well with those reported in other populations, ${ }^{810}$ confirming the genetic homogeneity of this disorder, as expected in view of the linkage disequilibrium between the DM mutation and flanking loci. ${ }^{1112}$ In addition, the present data indicate that the majority of Italian and Spanish DM symptomatic patients could be detected using a single DNA test. Eight percent of affected patients could only be identified by PCR. These observations are relevant to genetic counselling and prenatal diagnosis of this disease.

Association of the variable EcoRI fragment with DM.

\begin{tabular}{lccc}
\hline & \multirow{2}{*}{$\begin{array}{c}\text { Range of allele } \\
\text { expansion }(\mathrm{kb})\end{array}$} & \multicolumn{2}{c}{ Symptomatic DM patients } \\
\cline { 3 - 4 } Alleles & - & No & $\%$ \\
\hline E0 & $0-2$ & 86 & 8 \\
E1 & $2-4$ & 129 & 25 \\
E2 & $>4$ & 86 & 40 \\
E3 & &
\end{tabular}

- Not shown by Southern blotting. 
We are indebted to our Italian and Spanish colleagues who referred the patients to us. This work was supported by grants from the Italian CNR (PF IG no 91.00037.PF99 and PF Biotecnologie e Biostrumentazione), Telethon-Italy, project 'Molecular study of the DM gene', the Muscular Dystrophy Group of Great Britain, the Muscular Dystrophy Association of America, and the Central Research Fund of the University of London.

1 Harper PS. Myotonic dystrophy. 2nd ed. London: Saunders, 1989

2 Buxton J, Shelbourne P, Davies J, et al. Detection of an unstable fragment of DNA specific to individuals with unstable fragment of DNA specific to individ

3 Harley HG, Brook JD, Rundle SA, et al. Expansion of an unstable DNA region and phenotypic variation in myotounstable DNA region and phenotypic varic

4 Aslanidis C, Jansen G, Amemiya C, et al. Cloning of the essential myotonic dystrophy region and mapping of the putative defect. Nature 1992;355:548-51.

5 Fu YH, Pizzuti A, Fenwick RG, et al. An unstable triplet repeat in a gene related to myotonic dystrophy. Science 2.255:1256-8.

6 Brook JD, McCurrach ME, Harley HG, et al. Molecular basis of myotonic dystrophy: expansion of a trinucleotide (CTG) repeat at the $3^{\prime}$ end of a transcript encoding protein kinase family member. Cell 1992;68:799-808.

7 Griggs RC, Wood DS, the Working Group on the Molecular Defect in Myotonic Dystrophy. Criteria for establishing the validity of genetic recombination in myotonic dystrophy. Neurology 1989;39:420-1.

8 Mahadevan M, Tsilfidis C, Sabourin L, et al. An unstable CTG repeat in the $3^{\prime}$ untranslated region of the gene. Science 1992;255:1253-5.

$9 \mathrm{Fu} \mathrm{YH}$, Kuhl DP, Pizzuti A, et al. Variation of the CGG repeat at the fragile-X site results in genetic instability: resolution of the Sherman paradox. Cell 1991;67:1047-58.

10 Yamagata $\mathrm{H}$, Miki $\mathrm{T}$, Ogihara $\mathrm{T}$, et al. Expansion of unstable DNA region in Japanese myotonic dystrophy patients. Lancet 1992;339:692.

11 Harley HG, Brook DJ, Floyd J, et al. Detection of linkage disequilibrium between the myotonic dystrophy locus disequilibrium between the myotonic dystrophy locus and a new polym

12 Ashizawa T, Epstein HF. Ethnic distribution of myotonic dystrophy gene. Lancet 1991;338:642-3.

\section{Editor's note}

Dr Kay Davies, who edited this collection of papers on myotonic dystrophy, and who has been Molecular Genetics Editor of the fournal of Medical Genetics for the past six years, will step down from this position at the end of 1992. The Journal would like to take this opportunity of thanking Dr Davies for the major role she has played in helping it to develop during a time when molecular genetics has become an integral part of both research and clinical practice in medical genetics.

PETER S HARPER 